\title{
Growth Retardants Affect Landscape Performance of Zinnia, Impatiens, and Marigold
}

\author{
Joyce G. Latimer ${ }^{1}$ \\ Department of Horticulture, Georgia Experiment Station, University of \\ Georgia, Griffin, GA 30223-1797
}

Additional index words. Zinnia elegans, Impatiens wallerana, Tagetes erects, paclobutrazol, daminozide, ancymidol, drought, transplant establishment

\begin{abstract}
Various spray rates of paclobutrazol, $5000 \mathrm{ppm}$ daminozide, $200 \mathrm{ppm}$ ancymidol, or drought imposition (visible wilt symptoms for up to 2 hours daily) were applied to three bedding plant species to determine effects on growth in the greenhouse and the subsequent growth and performance of treated plants in the landscape. Seedlings of Zinnia efegans Jacq. 'Peter Pan Scarlet' responded to all growth retardants (paclobutrazol at 40 and $90 \mathrm{ppm}$ ) and the drought treatment in the greenhouse. However, zinnias treated with paclobutrazol or ancymidol still exhibited reductions in plant height 5 and 7 weeks after transplanting to the landscape, and in plant quality (subjective rating of plant appearance with emphasis on flower cover) at 5 weeks after transplanting. Daminozide or drought controlled zinnia growth in the greenhouse but had no carry-over effect in the landscape. Stem elongation of Impatiens wallerana Hook 'Accent Red' seedlings was moderately controlled by $20 \mathrm{ppm}$ paclobutrazol in the greenhouse. There were no other treatment effects in the greenhouse. Paclobutrazol $(20 \mathrm{ppm})$ reduced final plant height and quality ( 7 weeks postplanting). Treatment with daminozide or drought reduced plant width and quality after 5 and 7 weeks in the landscape. Ancymidol had no effect on landscape performance of impatiens. Shoot dry weight gain and stem elongation of Tagetes erects L. 'Papaya Crush' seedlings were reduced by ancymidol or $40 \mathrm{ppm}$ paclobutrazol in the greenhouse. Shoot dry weight gain of marigold seedlings was inhibited during the first week of landscape establishment by prior treatment with daminozide, ancymidol, or drought. Final plant height and width in the landscape were not affected by any treatment; however, $40 \mathrm{ppm}$ paclobutrazol, daminozide, or ancymidol decreased final plant quality. Chemical names used: $\alpha$-cyclopropyl- $\alpha$-(4-methoxyphenyl) -5-pyrimidinemethanol (ancymidol); butanedioic acid mono(2,2-dimethylhydrazide) (daminozide); $\beta$-[(4-chlorophenyl) methyl] - $\alpha$ (1,1-dimethylethyl)-1H-1,2,4-triazole-1-ethanol (paclobutrazol).
\end{abstract}

Plant growth retardants are commonly used in the production of bedding plants to control plant growth and habit during production and to improve plant appearance and quality during marketing. Species vary in responsiveness to plant growth retardants (Cathey, 1975), and optimum rates may vary with cultivar or growing conditions (Barrett and Bartuska, 1982).. Once transplanted to the landscape, the plants are expected to grow out of the treatments due to the new soil conditions and time. Residual effects may be more important with the use of the new triazole compounds, such as paclobutrazol, which appear to be active in plants for longer than the older growth retardants like daminozide and ancymidol (Davis et al., 1988).

Ancymidol improved stress tolerance of treated plants in the landscape (Cathey, 1975). Daminozide improved the quality of zinnia seedlings (Armitage et al., 1981) and extended the shelf life of bedding plants (Seeley, 1985). Paclobutrazol also improved

Received for publication 18 July 1990 . The cost of publishing 'this paper was defrayed in part by the payment of page charges. Under postal regulations, this paper therefore must be hereby marked advertisement solely to indicate this fact.

'Assistant Professor. drought tolerance of woody plants (Swietlik and Miller, 1983). The triazole compounds, paclobutrazol and uniconazole, reduced stem growth of verbena seedlings during greenhouse production, but the subsequent landscape performance of these plants was enhanced by the treatments via reduced lodging (Davis and Andersen, 1989). Paclobutrazol drench treatments during transplant production continued to reduce marigold growth in the landscape 138 days after treatment, while spray treatments were no longer effective (Keever and Cox, 1989). Preliminary work indicated that plant growth regulators enhanced early flowering but not later (6 weeks postplanting) quality of seedling geraniums planted to the field (Latimer and Killingsworth, 1988).

The purpose of the research reported here was to determine if growth retardants applied in the greenhouse during plant production would affect the subsequent establishment and performance of zinnia, impatiens, and marigold after they are transplanted to a landscape setting.

Plant culture. Three separate experiments were conducted in 1988 (Table 1). Seeds of 'Peter Pan Scarlet' zinnia and 'Papaya Crush' packs filled with Pro-Gro 200 seedling memarigold were sown directly into plastic cell- dium (Pro-Gro Products, Elizabeth City, N.C.). 'Accent Red' impatiens seeds were sown in seedling flats and transplanted to cell-packs 32 days after sowing. Each experiment was set up in a randomized complete block design with four replications of one flat of 32 (zinnia) or 48 (impatiens and marigold) plants for each treatment. Treatments consisted of paclobutrazol, daminozide, or ancymidol (Table 2) plus an untreated control and a drought treatment as a cultural control. Daminozide and ancymidol rates were those recommended by Heins et al. (1978), and paclobutrazol rates were selected from the high and low sides of recommended or previously reported rates for each species. Freshly prepared solutions were applied as directed sprays of $1.0 \mathrm{ml} / \mathrm{plant}$. The volume applied allowed little or no run-off onto the medium. A drought treatment was also included, whereby water was withheld daily until the seedlings exhibited visible wilt symptoms for up to $2 \mathrm{~h}$. The drought treatment was imposed as soon as the plants were large enough to deplete the moisture in the cell, which in these experiments was $\approx 16$ days after sowing (DAS) for zinnia, 50 DAS for impatiens, and 28 DAS for marigold. Drought-stressed plants were lightly watered in the late afternoon to prevent drought stress at night. The drought treatment was most severe and uniform the last 2 to 3 weeks of the experiment for each species. The other plants were maintained in well-watered condition by watering twice daily. All seedlings were fertilized twice weekly with $200 \mathrm{ppm}$ $\mathrm{N}$ of 20N-8.7P-16.6K (W.R. Grace \& Co., Cambridge, Mass.).

At the end of the greenhouse experiment (DAS listed in Table 1), six plants were randomly selected from each flat for growth analysis. Data included fresh and dry weights (72 $\mathrm{h}$ at $70 \mathrm{C}$ in a forced-air oven) of leaves and stems, dry weight of roots (handwashed free of medium), leaf area [LI-COR (Lincoln, Neb. ) 3000 leaf area meter] (not measured for impatient), and stem length (measured from the root/shoot interface of the stem to the bottom of the terminal bud of the main stem; no lateral shoots were included). On the day following growth analysis, the remaining plants were transplanted to the field, maintaining the randomized complete block design (four replications), to assess the effects of greenhouse treatments on the subsequent growth and performance of the plants. No additional treatments were imposed in the field. Zinnia and marigold seedlings were set one plant per $0.27 \mathrm{~m}^{2}$ in full sun in a field fertilized once with $13 \mathrm{~N}$ $5.8 \mathrm{P}-11 \mathrm{~K}$ at $896 \mathrm{~kg} \cdot \mathrm{ha}^{-1}$ Impatiens were set one plant per $0.18 \mathrm{~m}^{2}$ in a bed uniformly shaded by oak trees. The plants were irrigated by overhead sprinklers and mulched with hardwood chips.

Seven days after transplanting, six-plant samples were collected from each treatment in each block to determine shoot dry weight gain as an estimate of field establishment of the transplants. Plant height, the width of the plant taken at two perpendicular sites, and a plant quality rating were taken on five rep- 
Table 1. Description of timing of seeding and plant growth regulator (PGR) treatment, greenhouse environmental conditions, and time of growth analysis for three experiments.

\begin{tabular}{|c|c|c|c|c|c|c|}
\hline \multirow[b]{2}{*}{ Species } & \multirow{2}{*}{$\begin{array}{l}\text { Seeds } \\
\text { sown' } \\
\text { (date) }\end{array}$} & \multirow{2}{*}{$\begin{array}{l}\text { Root } \\
\text { cell vol } \\
\left(\mathrm{cm}^{3}\right)\end{array}$} & \multirow{2}{*}{$\begin{array}{l}\text { PGRs } \\
\text { applied } \\
(\mathrm{DAS})^{y}\end{array}$} & \multicolumn{2}{|c|}{ Greenhouse } & \multirow{2}{*}{$\begin{array}{c}\text { Growth } \\
\text { analysis } \\
\text { (DAS) }\end{array}$} \\
\hline & & & & $\begin{array}{c}\mathrm{PPF}^{\mathrm{x}} \\
\left(\mathrm{mol} \cdot \mathrm{m}^{-2} \cdot \mathrm{day}^{-1}\right)\end{array}$ & $\begin{array}{c}\text { Temp } \\
\left({ }^{\circ} \mathrm{C}, \text { day/night }\right)\end{array}$ & \\
\hline Zinnia & 5 May & 160 & 12 & 24.9 & $32 / 17$ & 32 \\
\hline Impatiens & 5 Apr. & 105 & 41 & 22.8 & $29 / 16$ & 77 \\
\hline Marigold & 23 Mar. & 105 & 19 & 24.0 & $31 / 16$ & 63 \\
\hline
\end{tabular}

Zinnia and marigold seeds sown directly into cell-packs; impatiens seeds sown in seedling flat and transplanted to cell-packs 32 DAS.

${ }^{y} \mathrm{DAS}=$ days after sowing.

${ }^{x} \mathrm{PPF}=$ photosynthetic photon flux.

Table 2. Effect of growth retardants on growth of zinnia, impatiens, and marigold in the greenhouse.

\begin{tabular}{|c|c|c|c|c|c|}
\hline Treatment & $\begin{array}{l}\text { Concn } \\
(\mathrm{ppm})\end{array}$ & $\begin{array}{l}\text { Leaf } \\
\text { area } \\
\left(\mathrm{cm}^{2}\right) \\
\end{array}$ & $\begin{array}{c}\text { Stem } \\
\text { length } \\
(\mathrm{cm})\end{array}$ & $\begin{array}{c}\text { Shoot } \\
\text { dry wt } \\
(\mathrm{mg})\end{array}$ & $\begin{array}{c}\text { Root } \\
\text { dry wt } \\
(\mathrm{mg})\end{array}$ \\
\hline \multicolumn{6}{|l|}{ Zinnia } \\
\hline Control & --- & $363 \mathrm{a}^{2}$ & $20.7 \mathrm{a}$ & $1643 \mathrm{a}$ & $300 \mathrm{~b}$ \\
\hline \multirow[t]{2}{*}{ Paclobutrazol } & 40 & $275 \mathrm{bc}$ & $12.4 \mathrm{C}$ & $1267 \mathrm{bc}$ & 346 a \\
\hline & 90 & $238 \mathrm{~cd}$ & $10.0 \mathrm{~d}$ & $1139 \mathrm{c}$ & $336 \mathrm{ab}$ \\
\hline Daminozide & 5000 & $311 \mathrm{~b}$ & $17.8 \mathrm{~b}$ & $1420 \mathrm{~b}$ & $321 \mathrm{ab}$ \\
\hline Ancymidol & 200 & $229 \mathrm{~d}$ & $8.8 \mathrm{~d}$ & $1161 \mathrm{c}$ & $332 a b$ \\
\hline Drought & --- & $295 \mathrm{~b}$ & $16.9 \mathrm{~b}$ & $1272 b c$ & $251 \mathrm{c}$ \\
\hline \multicolumn{6}{|l|}{ Impatiens } \\
\hline Control & --- & --- & $25.7 \mathrm{a}$ & 902 & 90 \\
\hline \multirow[t]{2}{*}{ Paclobutrazol } & 5 & --- & $25.5 \mathrm{a}$ & 864 & 105 \\
\hline & 20 & -- & $17.4 \mathrm{~b}$ & 628 & 74 \\
\hline Daminozide & 5000 & --- & $23.9 \mathrm{a}$ & 780 & 76 \\
\hline Ancymidol & 200 & --- & $23.6 \mathrm{a}$ & 702 & 86 \\
\hline \multirow[t]{2}{*}{ Drought } & --- & --- & $22.8 \mathrm{a}$ & 812 & 99 \\
\hline & & & & NS & NS \\
\hline \multicolumn{6}{|l|}{ Marigold } \\
\hline Control & --- & 283 a & $10.3 \mathrm{a}$ & $1918 \mathrm{ab}$ & $468 \mathrm{c}$ \\
\hline \multirow[t]{2}{*}{ Paclobutrazol } & 10 & $282 \mathrm{a}$ & $9.9 \mathrm{a}$ & $1870 a b$ & $737 \mathrm{a}$ \\
\hline & 40 & $239 \mathrm{~b}$ & $7.8 \mathrm{~b}$ & $1490 \mathrm{c}$ & $562 \mathrm{bc}$ \\
\hline Daminozidc & 5000 & $275 \mathrm{a}$ & $10.3 \mathrm{a}$ & $1954 \mathrm{a}$ & $676 \mathrm{ab}$ \\
\hline Ancymidol & 200 & $224 \mathrm{~b}$ & $8.1 \mathrm{~b}$ & $1460 \mathrm{c}$ & $558 \mathrm{bc}$ \\
\hline Drought & --- & $238 \mathrm{~b}$ & $11.1 \mathrm{a}$ & $1647 \mathrm{bc}$ & $454 \mathrm{c}$ \\
\hline
\end{tabular}

${ }^{2}$ Mean separation within columns and species by LSD, $P=0.05$.

'Leaf area not measured.

Table3. Effect of growth retardants and drought on shoot dry weight gain of marigold after 7 days in the landscape.

\begin{tabular}{lclc}
\hline \hline Treatment & $\begin{array}{c}\text { Concn } \\
(\mathrm{ppm})\end{array}$ & \multicolumn{1}{c}{ Regression equation } \\
\hline Control & -- & LSHDW $=0.180+0.045 \mathrm{x}$ & $R^{2,}$ \\
Paclobutrazol & 10 & LSHDW $=0.197^{\mathrm{NS}}+0.036 \mathrm{x}^{\mathrm{NS}}$ & 0.70 \\
& 40 & LSHDW $=0.094^{* *}+0.039 \mathrm{x}^{\mathrm{Ns}}$ & 0.57 \\
Daminozide & 5000 & LSHDW $=0.222^{*}+\left(3.026 \mathrm{X}^{* * *}\right.$ & 0.50 \\
Ancymidol & 200 & LSHDW $=0.119^{* *}+0.035 \mathrm{x}^{*}$ & 0.47 \\
Drought & --- & LSHDW $=0.139^{*}+0.032 \mathrm{x}^{* *}$ & 0.56 \\
\hline
\end{tabular}

${ }^{2}$ LSHDW is the log-transformed shoot dry weight $(\mathrm{g}) . \mathrm{x}=$ days after transplanting to the field. ${ }^{y}$ Coefficients tested against those of untreated plants, c test. Significance levels: $P<0.05(*), 0.01$ $(* *)$, or $0.001(* * *)$ or not significant (NS) at $\mathrm{P}=0.05$.

resentative plants from each treatment in each block to evaluate landscape performance at 5 and 7 weeks after transplanting for zinnia and impatiens and at 4 and 7 weeks after transplanting for marigold. Since most of the plants attained a uniform, mounded form, the quality rating was based primarily on flower cover $(9=$ excellent with many flowers to 1 = poor with few flowers). All data were subjected to analysis of variance and regression analysis using the general linear models procedure of SAS (Freund et al., 1986).

Plant growth in the greenhouse. All treatments reduced leaf expansion and stem elongation of zinnia plants (Table 2) in the fol- lowing order of severity of response: ancymidol > 90 ppm paclobutrazol > 40 ppm paclobutrazol $>$ drought $>$ daminozide. Reductions in dry weight gains of zinnia were less severe than restrictions in dimensional growth. Although shoot dry weight gain was reduced by all treatments, root dry weight gain was decreased only by drought. Paclobutrazol at $40 \mathrm{ppm}$ actually increased root dry weight gain by $15 \%$. All plants had a single flower bud present at the time of the growth analysis.

Impatiens growth in the greenhouse was quite variable and the only significant response to the treatments was a $32 \%$ reduction in stem elongation in plants treated with
20 ppm paclobutrazol (Table 2). Local conditions delayed field transplanting. Therefore, the plants were slightly overgrown, which may have affected these results. There were no treatment effects on the days required for flowering (data not presented).

Growth of marigold seedlings was effectively controlled by ancyrnidol or $40 \mathrm{ppm}$ paclobutrazol, where leaf area and stem length were $16 \%$ to $24 \%$ less than in controls (Table 2). Neither 10 ppm paclobutrazol nor daminozide affected leaf area, stem length, or shoot dry weight, but both treatments increased root dry weight compared to controls. Drought affected only leaf area. Although treatments did not affect the number of buds at the time of analysis, the average number of open flowers was reduced $(P<0.05)$ by ancymidol (0/plant) and 40 ppm paclobutrazol (0.1/ plant) as compared to controls (0.5/plant).

Plant growth retardants generally have the greatest effects on expanding or elongating cells, where inhibition of gibberellin synthesis rapidly causes reductions in stem elongation and leaf expansion (Tanimoto, 1987). Root growth is less affected, or may even be enhanced, by plant growth retardants $(\mathrm{Ku}-$ chenbuch et al., 1988). In this study, both zinnia and marigold exhibited increased root growth in response to the lower rates of paclobutrazol (Table 2). Flowering has been hastened or delayed by plant growth regulators depending on the species and often has varied with environmental conditions (Seeley, 1985).

Landscape establishment. Since treated plants were of different sizes at the time of transplanting to the field, a regression model based on shoot dry weight gain during the first week after transplanting was used to estimate the effects of treatments on plant establishment. There were no treatment effects on shoot dry weight gain of zinnia in the field (data not presented, $R^{2}=0.57$ to 0.77 ). Although drought increased the slope of the regression equation for impatiens transplanted to the field, the coefficients of determination were very low, ranging from 0.18 to 0.43 (controls, $R^{2}=0.30$, detailed data not shown). Subsequent work has indicated that increasing the establishment period to 14 to 21 days improves the fit $\left(R^{2}\right)$ of the model.

However, marigold plants exhibited a significant field establishment response to the treatments during the 7-day interval (Table 3). Paclobutrazol had no significant effect on the rate of shoot dry weight gain during landscape establishment, but daminozide, ancymidol (with a slope similar to that of $10 \mathrm{ppm}$ paclobutrazol), and drought decreased the slope of the regression equations relative to that of controls. These values represent the rate of shoot growth in the field over 7 days and indicate that some of the growth retardants were still actively affecting plant growth even at 52 days after treatment. Davis and Andersen (1989) observed accelerated growth of triazole-treated verbena planted in the field when measured between planting and 30 days postplanting for uniconazole or between 43 and 62 days postplanting for paclobutrazol, suggesting long-term growth effects with 


\begin{tabular}{|c|c|c|c|c|c|c|c|}
\hline \multirow[b]{2}{*}{ Treatment } & \multirow{2}{*}{$\begin{array}{c}\text { Concn } \\
(\mathrm{ppm})\end{array}$} & \multicolumn{2}{|c|}{ Plant ht $(\mathrm{cm})$} & \multicolumn{2}{|c|}{ Plant width $(\mathrm{cm})^{2}$} & \multicolumn{2}{|c|}{ Quality rating $^{y}$} \\
\hline & & $5 \mathrm{wk}$ & $7 \mathrm{wk}$ & $5 \mathrm{wk}$ & $7 \mathrm{wk}$ & $5 \mathrm{wk}$ & $7 \mathrm{wk}$ \\
\hline \multicolumn{8}{|l|}{ Zinnia } \\
\hline Control & --- & $29.0 \mathrm{a}^{\mathrm{x}}$ & $33.2 \mathrm{a}$ & 30.0 & 35.6 & $57 \mathrm{ab}$ & $79 \mathrm{~b}$ \\
\hline Paclobutrazol & 90 & $20.4 \mathrm{c}$ & $24.0 \mathrm{~b}$ & 27.9 & 34.5 & $47 \mathrm{c}$ & $75 \mathrm{bc}$ \\
\hline Daminozide & 5000 & $27.8 \mathrm{a}$ & $32.4 \mathrm{a}$ & 30.8 & 37.2 & $68 \mathrm{a}$ & $86 \mathrm{a}$ \\
\hline Ancymidol & 200 & $21.4 \mathrm{c}$ & $24.6 \mathrm{~b}$ & 28.9 & 34.8 & $47 \mathrm{c}$ & $78 \mathrm{~b}$ \\
\hline Lontrol & --- & $18.5 \mathrm{a}$ & $21.0 \mathrm{a}$ & $36.4 \mathrm{a}$ & $46.0 \mathrm{a}$ & $52 \mathrm{a}$ & $76 \mathrm{a}$ \\
\hline \multirow{2}{*}{ Paclobutrazol } & 5 & $16.8 \mathrm{a}$ & $21.2 \mathrm{a}$ & $33.9 \mathrm{ab}$ & $45.2 \mathrm{a}$ & $53 \mathrm{a}$ & $77 \mathrm{a}$ \\
\hline & 20 & $11.6 \mathrm{~b}$ & $17.3 \mathrm{~b}$ & $30.2 \mathrm{bc}$ & $42.8 \mathrm{a}$ & $48 \mathrm{a}$ & $68 \mathrm{~b}$ \\
\hline Daminozide & 5000 & $19.4 \mathrm{a}$ & $20.0 \mathrm{a}$ & $30.5 \mathrm{bc}$ & $37.7 \mathrm{~b}$ & $43 \mathrm{~b}$ & $61 \mathrm{C}$ \\
\hline Ancymidol & 200 & $18.2 \mathrm{a}$ & $20.7 \mathrm{a}$ & $32.3 \mathrm{abc}$ & $43.4 \mathrm{a}$ & $49 \mathrm{a}$ & $73 \mathrm{a}$ \\
\hline Drought & --- & $16.8 \mathrm{a}$ & $18.6 \mathrm{a}$ & $28.7 \mathrm{c}$ & $38.0 \mathrm{~b}$ & $39 \mathrm{~b}$ & $60 \mathrm{C}$ \\
\hline Daminozide & 5000 & 16.0 & 19.4 & 19.4 & 26.2 & $45 \mathrm{c}$ & $59 \mathrm{~b}$ \\
\hline Ancymidol & 200 & 15.3 & 18.8 & 20.2 & 27.2 & $41 \mathrm{c}$ & $59 \mathrm{~b}$ \\
\hline \multirow[t]{2}{*}{ Drought } & --- & 17.0 & 21.0 & 20.0 & 28.0 & $54 \mathrm{ab}$ & $66 \mathrm{a}$ \\
\hline & & NS & NS & NS & NS & & \\
\hline
\end{tabular}

${ }^{2}$ Mean of two perpendicular measurements.

'Qualitv rating: 9 = excellent to 1 = poor; data subjected to arcsin transformation for analysis and presentation.

${ }^{x}$ Mean separation within columns and species byLSD: $P=0.05$.

paclobutrazol. This regression method of testing treatment effects on plant establishment is useful in evaluation of cultural practices for many transplanted crops. However, these measurements evaluate only initial establishment and do not in any way predict final plant performance in the field.

Landscape performance. Although all zinnia plants were in bud at the time of transplanting, anthesis was delayed by daminozide and ancyrnidol. After 7 days in the landscape, $39 \%$ of the control plants had flowered, while flowering had occurred in only $5 \%$ and $9 \%$ of the plants treated with daminozide and ancymidol, respectively. However, after 15 days in the field, more than $75 \%$ of the plants in all treatments were in flower. Armitage et al. (1981) found that daminozide, but not ancymidol, delayed flowering in three of four tall cultivars of zinnia. Days to flower in zinnia were not affected by paclobutrazol (Cox and Keever, 1988).

In previous work with a more vigorous cultivar, Cox and Keever (1988) concluded that acceptable height control of zinnia seedlings could be obtained with spray applications of 250, 500, or 1000 ppm paclobutrazol. Under our conditions, good height control was obtained in the greenhouse with $40 \mathrm{ppm}$ paclobutrazol. However, even this concentration had long-term effects on landscape performance of zinnia (Table 4). Zinnias treated with 40 or $90 \mathrm{ppm}$ paclobutrazol or 200 ppm ancymidol 3 weeks before transplanting were still shorter than untreated plants after 7 weeks in the field (Table 4). Plant width was not affected by the growth retardants after S or 7 weeks in the field, but the plant quality rating was reduced by paclobutrazol or ancymidol after 5 weeks in the field. Landscape quality of plants in all treatments was very good when measured at 7 weeks after transplanting. Although daminozide delayed initial flowering, neither daminozide nor drought affected plant growth or quality at 5 or 7 weeks after transplanting.

Since impatiens exhibited very little response to the growth retardants in the greenhouse, the plants from each treatment were similar in size at the time of transplanting to the field, except those treated with $20 \mathrm{ppm}$ paclobutrazol, which also were the shortest plants even after 7 weeks in the field (Table 4). Neither daminozide nor drought treatments affected plant height in the field, but both treatments resulted in less lateral expansion and a lower plant quality rating, while there was no effect of $5 \mathrm{ppm}$ paclobutrazol or ancymidol on landscape performance. Paclobutrazol rates previously reported for use on impatiens include 20,40, or $80 \mathrm{ppm}$, all of which failed to control plant height (Barrett and Nell, 1986) and 30,60, and 120 ppm, all of which reduced stem elongation by more than $50 \%$ (Gianfagna and Wulster, 1988). Differences in response maybe due to application methods, plant age, cultivars, or growing conditions (Barrett and Bartuska, 1982).

Marigold growth measured as plant height or width showed no carry-over effects from treatment with growth regulators (Table 4), which agrees with the results of Keever and Cox (1989). However, quality, based primarily on plant flowering, was reduced by all growth retardant treatments but not by drought after 4 weeks in the field and by all growth retardants, except $10 \mathrm{ppm}$ paclobutrazol, after 7 weeks in the field, relative to controls.

Although plant growth retardants, in many cases, are essential for the production of highquality bedding plants, growth retardants may not subsequently improve plant quality in the landscape. In most cases presented here, plant height of treated plants approximated that of the untreated controls after 5 to 7 weeks in the landscape, and in over half the cases, there was no reduction in plant quality relative to that of the untreated plants. Recommendations for growth retardant rates should include consideration of the long-term effects of the chemical on landscape performance of bedding plants. Drought conditioning during production did not affect the landscape performance of zinnia or marigold but decreased lateral growth and quality of impatiens.

\section{Literature Cited}

Armitage, A. M., R.E. Bass, W.H. Carlson, and L.C. Ewart. 1981. Control of plant height and flowering of zinnia by photoperiod and growth retardants. HortSciencc 16:218-220.

Barrett, J.E. and C.A. Bartuska. 1982. PP333 effects dependent on site of application. HortScience 17:737-738.

Barrett, J.E. and T.A. Nell. 1986. Evaluation of XE-1019 and palcobutrazol for height control of flowering annuals. Proc. Plant Growth Regulat. Soc. Amer. 13:62-64.

Cathey, M. 1975. Comparative plant growth-retarding activities of ancymidol with ACPC, phosfon, chlormequat, and SADH on ornamental plant species. HortScience 10:204-216.

Cox, D.A. and G.J. Keever. 1988. Paclobutrazol inhibits growth of zinnia and geranium. HortScience 23:1029-1030.

Davis, D. and A.S. Andersen. 1989. Post-production growth and flowering of triazole-treated Verbena rigida bedding plants. Gartenbauwissenschaft 54(3)S:109-112.

Davis, T. D., G.L. Steffens, and N. Sankhla. 1988. 
Triazole plant growth regulators. Hort. Rev. 10:63-105.

Freund, F. J., R.C. Littell, and P.C. Spector. 1986. SAS system for linear models. SAS Institute, Cary, N.C.

Gianfagna, T. and G. Wulster. 1987. Using sterolinhibiting compounds as both fungicide and growth retardant in bedding plant production. Bedding Plant Foundation 1986-87 Annu. Rpt.

Heins, R., R.E. Widmer, and H.F. Wilkins. 1978. Growth regulators effective on floricultural crops. Flor. Rev. 162(4206):32-35.

Keever, G.J. and D.A. Cox. 1989. Growth inhibition in marigold following drench and foliar- applied paclobutrazol. HortScience 24:390.

Kuchenbuch, R., W. Wiegelt, and J. Jung. 1988. Modification of root-shoot-ratio of sunflower (Helianthus annuus L.) by nitrogen supply and a triazole-type plant growth regulator. Z. Pflanzenernähr. Bodenk. 151:391-394.

Latimer, J.G. and S.B. Killingsworth. 1988. Effect of plant growth regulators on growth and landscape establishment of 'Ringo' geraniums. Proc. Southern Nurserymen's Assn. Res. Conf. 33:226-230

Seeley, J.G. 1985. Finishing bedding plants-effects of environmental factors-temperature, light, carbon dioxide, growth regulators, p. 212-244. In: J.W. Mastalerz and E.J. Holcomb (eds.). Bedding plants 111. Pennsylvania Flower Growers, University Park, Pa.

Swietlik, D. and S.S. Miller. 1983. The effect of paclobutrazol on growth and response to water stress of apple seedlings. J. Amer. Soc. Hort. Sci. 108:1076-1080.

Tanimoto, E. 1987. Gibberellin-dependent root elongation in Lactuca sativa: Recovery from growth retardant-suppressed elongation with thickening by low concentration of $\mathrm{GA}_{3}$. Plant Cell Physiol. 28:963-973. 